\title{
ON THE USE OF TENSIOMETERS IN SNOW HYDROLOGY
}

\author{
By S. C. Colbeck \\ (U.S. Army Cold Regions Research and Engineering Laboratory, Hanover, New \\ Hampshire 03755, U.S.A.)
}

\begin{abstract}
The construction and use of snow-water tensiometers is described. Water pressure at the base of a shallow, Arctic snow-pack was measured to illustrate the response of the basal layer to water percolation. Water tension above an ice layer and water flux through the ice layer were measured in glacial snow. The gravity flow theory is used to explain the close agreement between these parameters. This suggests that the ice layer has little effect on the flow field and that gravity (rather than tension gradients) controls the flow. Further work on water tensions is needed to identify the role of tension gradients in ripening and shallow snow covers.
\end{abstract}

RÉsumÉ. Sur l'utilisation de tensiomètres en hydrologie nivale. On décrit la construction et l'utilisation de capteurs de tension d'eau dans la neige. La pression d'eau à la base d'un manteau neigeux arctique peu profond a été mesurée de manière à illustrer la réponse du niveau de base à la percolation aqueuse. La tension de l'eau au-dessus d'un niveau de glace et le flux d'eau à travers ce niveau sont mesurés dans le neige de glacier. La théorie de l'écoulement gravitaire explique la bonne concordance entre ces paramètres. Ceci permet de penser qu'un niveau de glace a peu d'effet sur le champ de l'écoulement et que la gravité (plus que les gradients de tension) contrôle l'écoulement. Il faut un nouveau développement sur les tensions d'eau pour élucider le rôle des gradients de tension dans les manteaux neigeux peu puissants et en cours de maturation.

Zusammenfassung. Über den Gebrauch von Tensiometern in der Schnee-Hydrologie. Es wird die Konstruktion und der Gebrauch von Schnee-Wasser-Tensiometern beschrieben. Der Wasserdruck am Grunde einer flachen arktischen Schneedecke wurde gemessen mit dem Ziel, den Einfluss des Sickerwassers auf die Grundschicht aufzuzeigen. Die Spannung des Wassers über einer Eisschicht und der Wasserfluss durch die Eisschicht wurden in glazialem Schnee gemessen. Zur Erklärung der nahen Übereinstimmung zwischen diesen Parametern wird die Theorie des Schwerkraftflusses herangezogen. Daraus lässt sich schliessen, dass die Eisschicht nur geringen Einfluss auf das Strömungsfeld nimmt und die Schwerkraft (weit mehr als die Spannungsgradienten) den Fluss bestimmt. Zur Ermittlung der Rolle von Spannungsgradienten in verfenden und flachen Schneedecken sind weitere Studien zur Wasserspannung notwendig.

In situ instrumentation has been used for many years to measure the negative water pressure (tension) in unsaturated soils. These instruments, called tensiometers by Richards and Gardner (1936), have important applications in both the research and applied aspects of snow hydrology. Their use in snow is identical in principle to their use in soils, however, the details of the design and application are necessarily different because of the inherent differences between the two porous media. The basic principles are described by Bear (1972, p. 477).

The tensiometer senses the negative gage pressure of the liquid phase of the pore space. The liquid pressure in snow is determined by the geometry of the porous matrix and its liquid water content. For a ripe snow-pack where grain sizes are mostly in the range of $I$ to $2 \mathrm{~mm}$ in diameter, the snow density alone represents the porous matrix. For a given matrix the liquid pressure is directly related to the geometry of the water-air menisci or the water volume, i.e. the liquid water content. The relation between water tension and water saturation given for one snow sample by Colbeck (1973) is typical of hygroscopic porous media with large grains.

A Coors porous porcelain cylinder (P-I6-C) was used to permit liquid movement between the pressure transducer and snow (see Fig. I). The P-I6-C material allowed rapid water flow but prevented air entry because of the small pore sizes. Several pressure-sensing transducers were tested and the Endevco Model $8504 \mathrm{~A}$ with a standard range of $\pm 6900 \mathrm{~N} / \mathrm{m}^{2}$ was selected for use with snow. This transducer was excited by 10 V D.C. from a power supply. The voltage output increased linearly with pressure up to $500 \mathrm{mV}$ at $6900 \mathrm{~N} / \mathrm{m}^{2}$. 


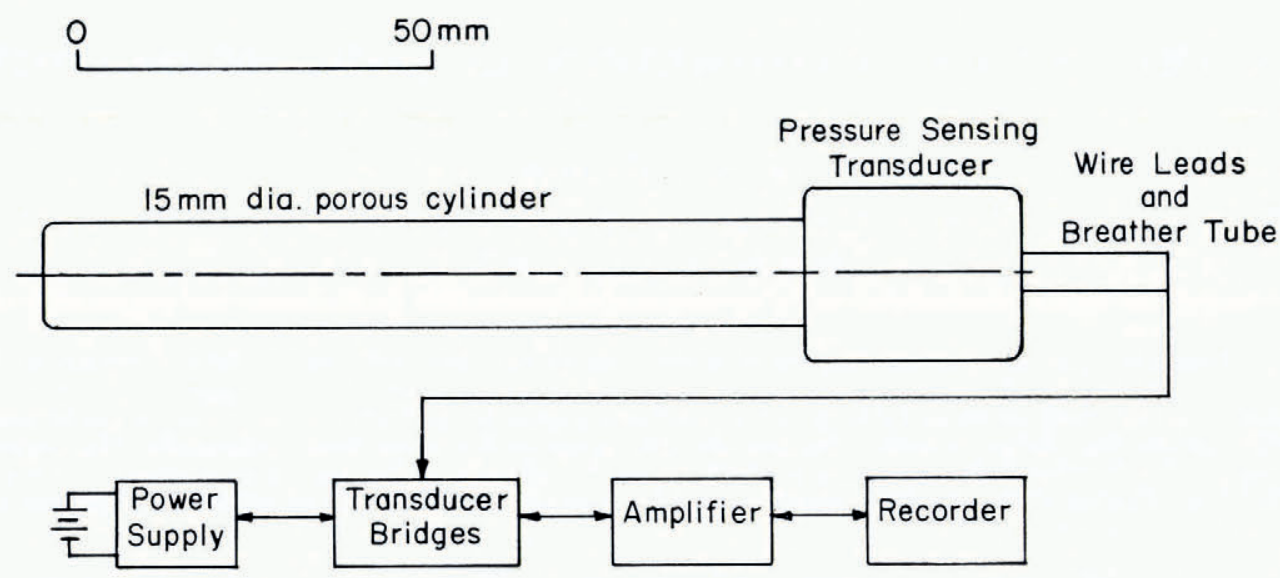

Fig. $r$. Schematic diagram of the pressure transducer and its associated electronics. The hollow, ceramic cylinder allows free liquid movement between the pressure transducer and the pore water of the snow.

Excluding any zero offset, the output was symmetrical about the origin, and pressure changes from the saturated to the unsaturated regimes could be continuously measured. The system response to pressure changes was on the order of milliseconds because of the very small volume necessary to displace the sensor diaphragm.

For a single sensor the electronics can be packaged in a $0.15 \mathrm{~m} \times 0.15 \mathrm{~m} \times 0.10 \mathrm{~m}$ box with a small external battery. This package allows much flexibility and ease of installation. The most difficult aspect of using this system is achieving an adequate contact between the porous cylinder and the liquid phase in highly unsaturated snow. This problem is common with large-grain porous media and occurs because the liquid phase separates at the porcelainsnow contact. The useful range of the tensiometer can be extended to larger tensions by using another material to interface between the ceramic and the snow. Wrapping soaked cotton around the porcelain cylinder and packing snow tightly around the tensiometer provides a better contact at high tensions. This technique has been successfully used to measure tensions as large as $0.90 \mathrm{~m}$ of water column $\left(8800 \mathrm{~N} / \mathrm{m}^{2}\right)$. While some local disturbance of the snow properties and flow field will occur, the pressure field as sensed by the instrument is not significantly affected by the presence of the disturbed snow. That is, the transducer senses pressures in the undisturbed snow because the temporal rate of change of the pressure in the undisturbed snow is small compared to the rate at which pressure is equalized between the undisturbed snow and the pressure transducer. In effect the disturbed area can be thought of as part of the tensiometer itself and, as long as the scale is about $0.10 \mathrm{~m}$, the response time of the system will be negligible.

Two applications of tensiometers to snow studies are presented to illustrate their potential use. Figure 2 shows water pressure measured just above the ground surface near Barrow, Alaska. The tensiometer was placed in a $0.85 \mathrm{~m}$ deep snowdrift which covered a slightly inclined, frozen surface. According to the measured pressure, water "ponded" on the frozen ground surface during the afternoon of ro June. The depth of the saturated layer reached its peak at $18.00 \mathrm{~h}$. Just after $20.00 \mathrm{~h}$ the phreatic surface passed the level of the tensiometer and the water tension increased as water drained away from the bottom of the snow-pack. At $13.00 \mathrm{~h}$ on I I June, the front of that day's melt-water wave reached the tensiometer, reducing the tension and starting to build another saturated layer. The weather was much cooler on II June, which reduced the surface melt and the saturated layer never fully developed. Accordingly, the water tension was larger than on the previous day. Note that the 


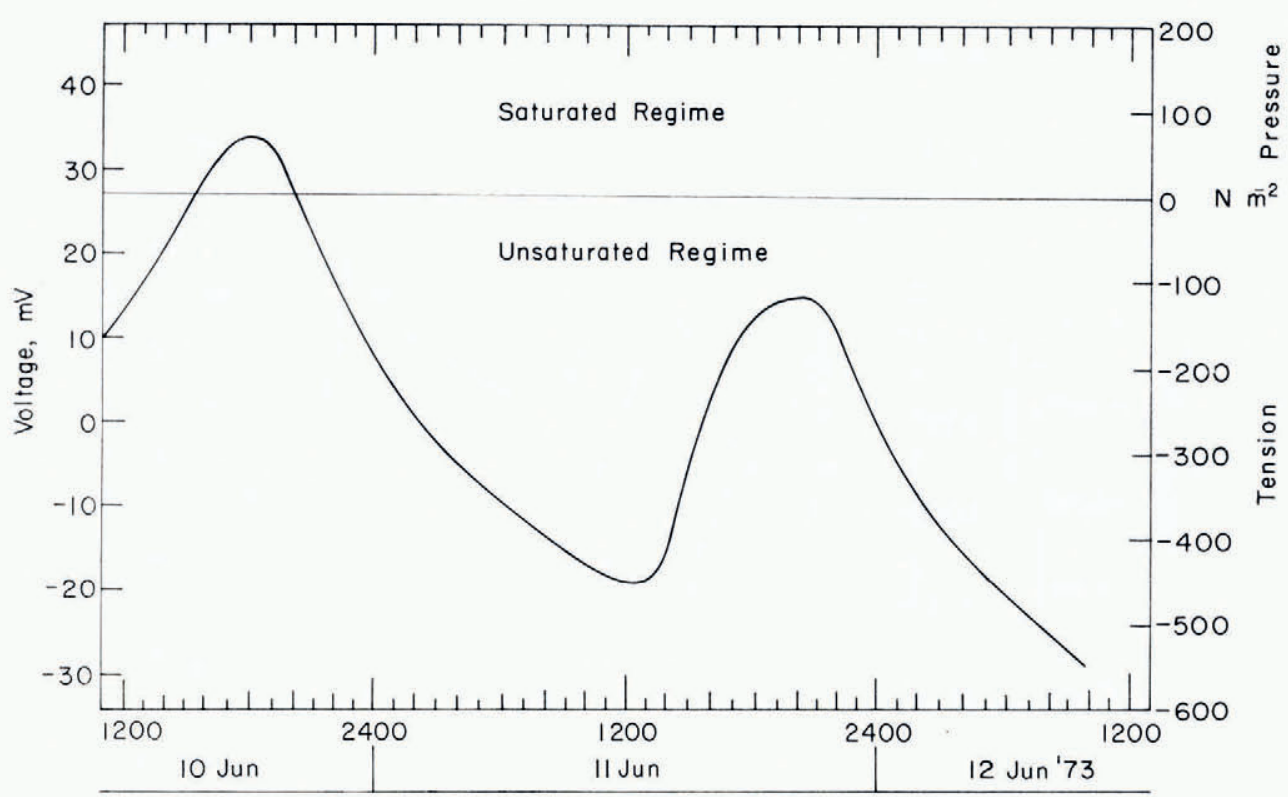

Fig. 2. Water pressure measured just above the ground surface in a shallow snowpack near Barrow, Alaska. The snow was saturated briefly on 10 June at the level of the tensiometer. The surface melting on I I June was less intense.

pressure increase began later on I I June than on io June because of the slower moving wavefront associated with higher tensions and lower saturations. The relationship between rate of propagation of the wavefront and water saturation given by Colbeck (I974[b]) explains this behavior. The equation for "lag" time used in run-off forecasting expresses a similar idea (Anderson, 1973).

Tensiometers were also used to measure water tensions in a deep snow-pack on the South Cascade Glacier, Washington. The tensiometer was placed $2.07 \mathrm{~m}$ below a snow surface experiencing heavy diurnal melting. The water movement through this unsaturated snow was collected with a funnel (see Sharp, [1952]) at a point $2.5 \mathrm{~m}$ below the surface and $2 \mathrm{~m}$ to the side of the tensiometer. The horizontal separation of the tensiometer and funnel was necessary to prevent interference. The funnel and tensiometer were separated vertically by a $50 \mathrm{~mm}$ ice layer. The ice layer had a solid appearance but water flowed freely through it. The collection funnel had an area of $0.17 \mathrm{~m}^{2}$ and collected melt water only from a corresponding area on the surface, which indicates that the ice layer did not change the mean flow averaged over a $0.17 \mathrm{~m}^{2}$ area. In this instance the infiltration into each $0.17 \mathrm{~m}^{2}$, as determined from surface ablation measurements (Wendell Tangborn kindly provided these data), was equal to the daily interception of flow by the collection funnel.

On Figure 3 the maximum tension measured at $2.07 \mathrm{~m}$ depth is timed closely with the minimum flow rate measured at $2.5 \mathrm{~m}$ depth and the minimum tension is timed closely with the maximum flow rate, regardless of their separation by a $50 \mathrm{~mm}$ ice layer and several meters of distance. This provides a good qualitative confirmation of the validity of using tensiometers to observe the advancing front of the diurnal melt-water wave.

The volume flux of water $\left(u_{\mathrm{w}}\right)$ can be quantitatively related to the water tension through the gravity drainage theory proposed by Colbeck (1972) and modified by Colbeck and Davidson (1973). They show

$$
u_{\mathrm{w}}=\alpha k S^{\star 3}
$$




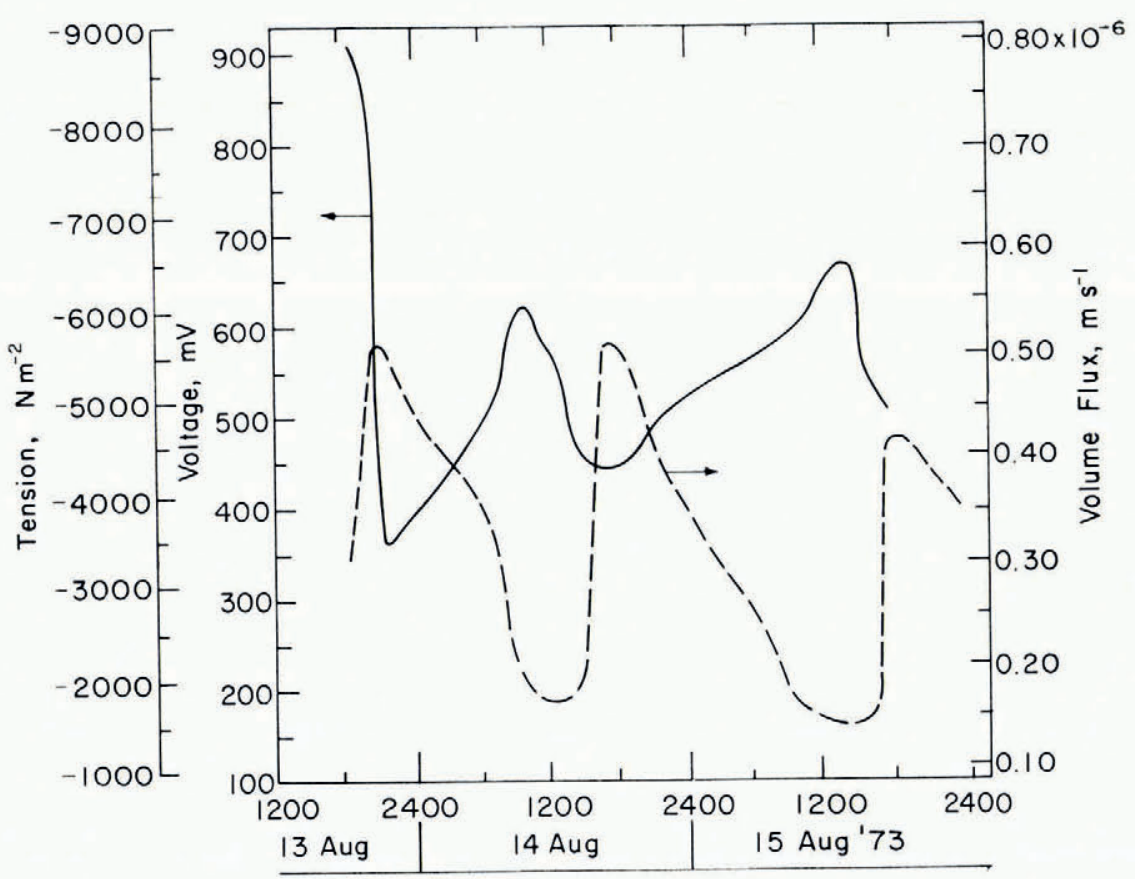

Fig. 3. Water tension and flux measured in the deep snowcover on the South Cascade Glacier. The flux and tension vary in opposite directions but in phase in response to changes in water content.

where $\alpha$ is a constant, $k$ is the intrinsic permeability of the pore space, and the effective water saturation $S^{\star}$ can be related to water tension for any given type of snow. Using the experimental relationship for snow of a similar density to the glacial snow cover (Colbeck, I974[a])

$$
p_{\mathrm{c}}=\left(43^{S^{\star-1}}+380\right) \mathrm{N} \mathrm{m}^{-2},
$$

water tension and capillary pressure are essentially identical at large tensions where air moves throughout the pore space in continuous paths. Using Equations (I) and (2), $u_{\mathrm{w}}^{-\frac{1}{5}}$ is proportional to the quantity $\left(p_{\mathrm{c}}-\right.$ constant $)$. Excluding the first few hours of operation, the correlation between $u_{\mathrm{w}}^{-\frac{1}{3}}$ and water tension is remarkably good (see Figure 4) considering the limitations of the experiments. The melt-water wave front and peak flux arrive first at the tensiometer because it is closer to the snow surface.

During other tensiometer experiments with seasonal snow covers, the thickness and timing of the saturated layer of water at the base of the snow-pack have been measured and correlated with the timing of the snow-pack run-off. This experiment demonstrates the validity of the two-layer theory for predicting run-off (Colbeck, I974[c]) and the applicability of tensiometers in both the research and applied aspects of snow hydrology. A complete system for forecasting the intensity and timing of snow-cover run-off could be constructed by measuring water tensions at several points in the unsaturated layer and the saturated layer. This would provide sufficient information to predict run-off from knowledge of the speed and intensity of the diurnal melt-water wave and the wave propagating through the saturated layer.

Much work must still be done on the movement of water through snow, and tensiometers can provide the same basic information to snow hydrologists which soil scientists have used for many years. For example, the information given here tends to disprove the common 


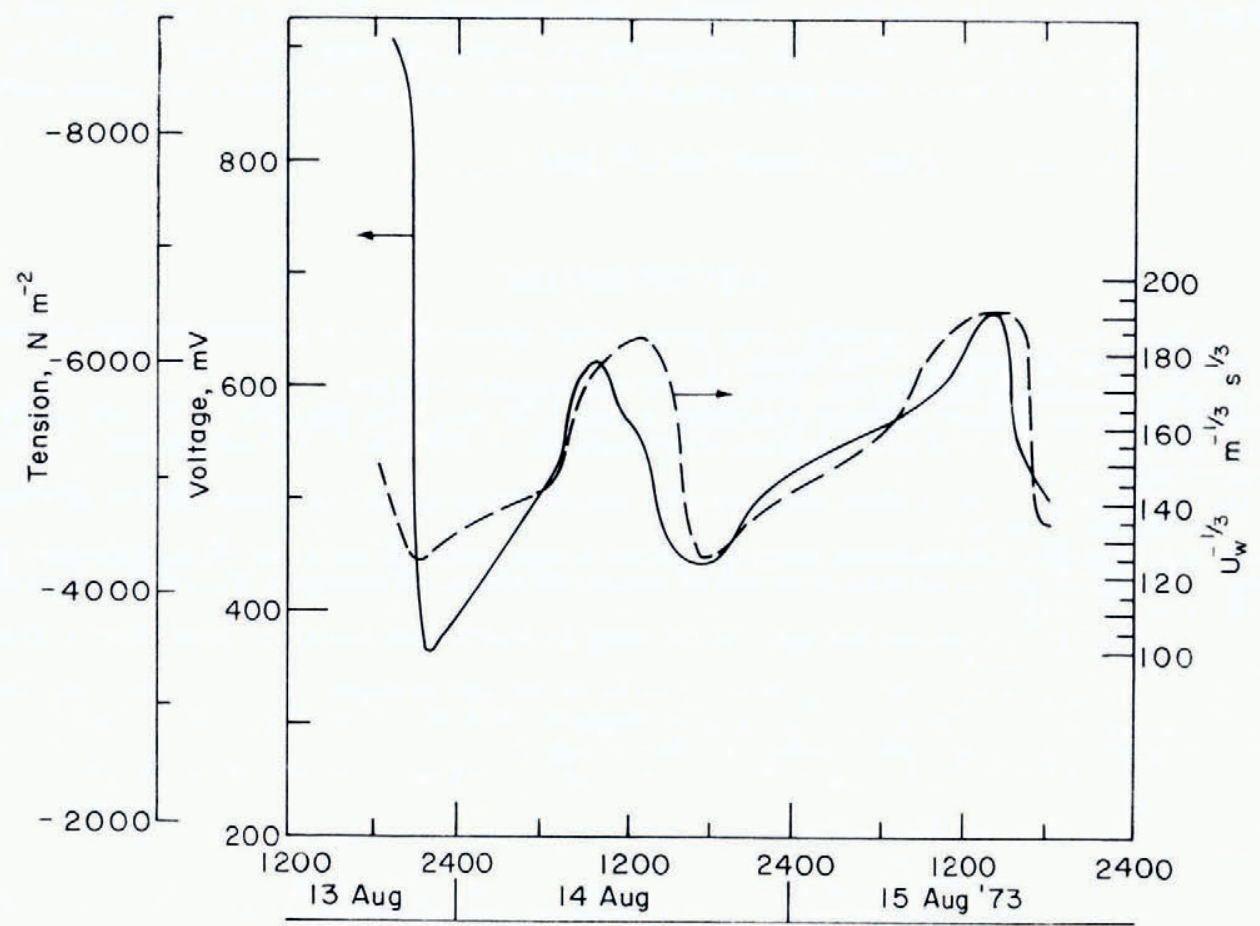

Fig. 4. Water tension and $u_{\mathrm{w}}^{-\frac{1}{3}}$ for the glacial snow closely correlate in spite of the distance and ice layer separating the tensiometer and funnel.

assertion that water movement through snow containing ice layers occurs in response to tension gradients since tension gradients were ignored in the construction of Figure 4 . When the physics of water movement through ripening snow-packs (especially seasonal snow-packs in temperate zones) is investigated, tensiometers should play a major role in identifying the role of tension gradients. The matrix of unripened snow consists of a large number of smaller, angular particles which should significantly alter the tension-saturation relation and may affect the relative significance of the tension gradient and gravity effects on unsaturated flow. While the water-filled tensiometers described here cannot be placed in sub-freezing snow covers, the glycol-filled tensiometers being developed for use in frozen soils may be installed in sub-freezing snow prior to the onset of water infiltration.

The tensions measured in both glacial and seasonal snows are higher than expected from the tension-saturation data of Colbeck (1973). This discrepancy suggests that the data obtained in the laboratory do not represent the true capillary equilibrium values because the experiments were completed too quickly. The difference between the residual and equilibrium values of saturation are explained by Harris and Morrow (1964). Obviously, much work on the occurrence and movement of liquid water through snow must yet be done and tensiometers should be one of the basic tools for these investigations.

\section{AgKnowledgements}

These instruments were developed as a tool for use in snow while funding was supplied by Project $4 \mathrm{Al}_{1} \mathrm{II}_{102} \mathrm{~B}_{52} \mathrm{E} / \mathrm{o2} / \mathrm{o}$ I 1 of the U.S. Army Corps of Engineers. The field facilities of the U.S. Geological Survey at South Cascade Glacier were generously supplied through 
Dr Mark F. Meier. Dr Harlan L. McKim and Michael A. Bilello assisted by critically reviewing this manuscript. My wife, Margaret, provided assistance during the field trials. Mr John Kalafut of CRREL designed and built the electronic packages for the tensiometers.

MS. received I8 March 1975 and in revised form 26 June 1975

\section{REFERENCES}

Anderson, E. A. 1973. National Weather Service river forecast system-snow accumulation and ablation model. NOAA Technical Memorandum, NWS HYDRo-I 7.

Bear, J. 1972. Dynamics of fluids in porous media. New York, American Elsevier.

Colbeck, S. C. 1972. A theory of water percolation in snow. Fournal of Glaciology, Vol. I 1, No. 63, p. 369-85.

Colbeck, S. C. 1973. Theory of metamorphism of wet snow. U.S. Cold Regions Research and Engineering Laboratory. Research Report 313.

Colbeck, S. C. 1974[a]. The capillary effects on water percolation in homogeneous snow. Fournal of Glaciology, Vol. ${ }_{3}$, No. 67, p. $85-97$.

Colbeck, S. C. $1974[\mathrm{~b}]$. On predicting water runoff from a snow cover. (In Santeford, H. S., and Smith, J. L., comp. Advanced concepts and techniques in the study of snow and ice resources. Washington, D.C., National Academy of Sciences, p. 55-66.)

Colbeck, S. C. 1974[c]. Water flow through snow overlying an impermeable boundary. Water Resources Research, Vol. io, No. I, p. i 19-23.

Colbeck, S. C., and Davidson, G. 1973. Water percolation through homogeneous snow. (In [International Hydrological Decade.] The role of snow and ice in hydrology. Proceedings of the Banff symposia, September 1972. Paris, UNESCO; Geneva, WMO; Budapest, IAHS, p. 242-57.)

Harris, C. C., and Morrow, N. R. 1964. Pendular moisture in packings of equal spheres. Nature, Vol. 203, No. 4946, p. 706-08.

Richards, L. A., and Gardner, W. 1936. Tensiometers for measuring the capillary tension of soil water. Fournal of the American Society of Agronomy, Vol. 28, No. 5, p. 352-58.

Sharp, R. P. [1952.] Meltwater behavior in firn on upper Seward Glacier, St. Elias Mountains, Canada. Union Géodésique et Géophysique Internationale. Association Internationale d'Hydrologie Scientifique. Assemblée générale de Bruxelles, 195I, Tom. I, p. 246-53. 